\title{
The application of systems theory framework in understanding school communities' cultural values towards guidance and counselling services
}

\author{
Nurul Ain Mohd Daud* \\ Faculty of Education and Human Development, Sultan Idris Education University, Tanjung Malim, Malaysia
}

\section{A R T I C LE IN F O}

\section{Article history:}

Received 25 August 2016

Received in revised form

25 October 2016

Accepted 1 November 2016

\section{Keywords:}

Systems theory framework

Guidance and counselling

Cultural values

Qualitative study

Systemic issues

\begin{abstract}
A B S T R A C T
This paper discusses the application of Systems Theory Framework (STF) in understanding school guidance and counselling services. It highlights the experiences of the researcher who conducted her qualitative study on cultural values towards guidance and counselling in one school in Malaysia. The sample of the study consisted of 41 students, 2 teachers, 8 school counsellors and 5 administrators. Semi structured individual interviews and focus groups were conducted to elicit their experiences. The findings indicated that systemic issues were associated with negative values towards the service. The study provides the implication of STF in regard to understand the school guidance and counselling services as a system. The characteristics demonstrated by STF enabled the researcher to comprehend the holistic picture of guidance and counselling services and the school communities' acceptance towards the service.
\end{abstract}

(C) 2016 The Authors. Published by IASE. This is an open access article under the CC BY-NC-ND license (http://creativecommons.org/licenses/by-nc-nd/4.0/)

\section{Introduction}

School is considered a unique place that can provide required support for addressing multiple aspects of students' diversity, including race, sexual orientation, socioeconomic status, at-risk students and underachievers (Yeh, 2003). In the Malaysian context, school is regarded as a platform for unity among different racial backgrounds (Sapora, 2007). It is also a place specifically to inculcate knowledge, values and morality to produce well-rounded students. The existence of guidance and counselling services in every school has been regarded as the catalyst to achieve these proposed aims. However these efforts will be hampered if the acceptance of the counselling service is withheld or only partial. Hence, it is important for school counsellors to understand school communities' attitudes and expectations towards counselling services.

\section{Literature review}

Most research conducted in Malaysia indicated participants' negative perceptions and experiences towards counselling services in secondary schools or

\footnotetext{
* Corresponding Author.

Email Address: nurul.ain@fppm.upsi.edu.my (N. A. M. Daud)

https://doi.org/10.21833/ijaas.2016.11.005

2313-626X/@ 2016 The Authors. Published by IASE.

This is an open access article under the CC BY-NC-ND license

(http://creativecommons.org/licenses/by-nc-nd/4.0/)
}

at the level of higher institutions. Quantitative study conducted by Li (2004) on 214 forms four students in one rural secondary school in Kuching, Malaysia. The findings indicate that the students' low level of participation in counselling was mainly due to their internal inclination to the service, including unreadiness to reveal to a stranger, communication barrier and doubts about confidentiality of the counselling session whereby a significant difference was exhibited between the academically good and academically poor students on their external reasons for not seeking counselling. The findings of the study also show that students seek counselling because they were well-informed about the counselling services - knew the importance, benefits and understood the counselling process.

However, despite having considerable knowledge and information about the service, the level of acceptance towards the service was still relatively low among participants. It was revealed through a comprehensive quantitative study conducted by Sidek et al. (2005), which involved 107 school principals, 88 school counsellors, 628 teachers and 1984 school students in few secondary schools in Peninsular Malaysia, that although 96.6 per cent of participants heard about counselling and 92.7 per cent knew the role of the service in school, only 32.4 per cent of them used the service. These findings indicate that the level of acceptance of counselling services among Malaysian students is still relatively low because of the perceived irrelevant role and 
contribution of counsellor and counselling services in their life.

Other quantitative studies, by Rusnani et al. (2008) regarding the attitudes and help seeking attitudes among Malaysian undergraduate university students, also revealed similar negative attitudes. There was a significant difference in the attitudes of male and female participants in both studies but no significant difference was accounted between racial groups - Malay, Chinese and Indian - in the latter study. However, there was a significant difference in the former study between those who were exposed to the service and those who were not. However, neither study offered a detailed explanation about the students' negative attitudes. Hence, an in-depth study needs to be conducted to explore and understand the root cause of their attitude otherwise it will remain a cyclical pattern forever.

The whole school approach of counselling is also connected to the acceptance of or willingness to use the service. A qualitative study conducted by Hui (2002) revealed an overall mismatch between the beliefs of teachers in Hong Kong about a whole school approach to guidance and its practice and their perceived school reality. The majority of them perceived that a whole school approach was not practiced by the school community, and, thus, affected their cooperation and participation in the service. Similar patterns of findings were also revealed by Loynd et al. (2007) who conducted two phases of studies; quantitative and qualitative study with 71 and 33 Scottish secondary school teachers. A misconception occurred in respect of the role and conception of counselling in schools whereby they perceived counselling as an independent entity, and, hence, provided less cooperation to the school counsellors. Hence, these studies indicated the importance of a whole school approach as a system in fostering student development and enhancing team spirit among school communities towards a counselling service.

In this regard, it can be concluded that addressing cultural values is essential in exploring the attitude of unwillingness toward counselling.

\section{Theoretical framework}

\subsection{Systems theory framework (STF)}

This study embraces Systems Theory Framework (STF) as a guideline for understanding cultural values towards guidance and counselling services. STF has come from multidisciplinary fields such as physics, biology, anthropology and psychology (Patton and McMahon, 2006). It has been proposed as a potential framework for dealing with many issues in human behavior. This framework has put its central focus not only on the individual system, which constituted intrapersonal influences, such as personality, ability, gender, and sexual orientation, but also on their interpersonal influences, such as connection with the broader social system - family, socioeconomic status, school, etc.
System theory has been used extensively by Patton and McMahon in their research and writing particularly career counselling framework (2006; 2014). This framework has challenged traditional career theory in viewing the position of a person in relation to his or her career development. In explaining career development, this systems framework not only places its emphasis on individual characteristics, such as self-concept, personality, belief systems to name but a few, but also includes interpersonal aspects of human beings. Thus, this conception is considered holistic in viewing the position of an individual in relation to his or her society as it celebrates the importance of both elements; personal and interpersonal in explaining human behavior.

This framework is seen to be practical in the sense that it demonstrates the process and relationship of the individual in a system. The fundamental principle in understanding the STF is that it embraces an open system that is subject to influence from outside and beyond its boundaries. This perspective is also in line with Constructivism view that stresses the person as an open system, constantly interacting with the environment, seeking stability through ongoing change. This framework regards human development as a dynamic process. It is clearly explained by the process of recursiveness, change over time and chance.

\section{Objectives}

The purpose of this research is to explore and understand the aspect of cultural values inherent in the life of students and school communities, and how these influence their appreciation of guidance and counselling services.

\section{Research methodology}

This study embraced qualitative methods specifically narrative ethnography, using case study approach as it seeks to understand and examine indepth cultural experiences of participants (Ponterotto, 2005). This is in line with Adams et al. (2007) that qualitative research is appropriate for various aspects of cultural studies because it has the ability to examine in-depth the multicultural issues and provide open-ended responses for exploring and understanding participants in multicultural research.

\subsection{Participants}

Information was elicited through in-depth case studies of 41 students, eight (8) school counselors, two (2) school teachers, and five (5) school administrators. The participants were fully informed about the study and were assured of confidentiality and anonymity.

\subsection{Data collection methods and analysis}


The study employed semi structured interviews as well as focus group interviews to understand the participants' experiences. Ethics approval was obtained from the ethics committee of the university, and written consent were obtained from all the participants. The study used constant comparative analysis of constructivist grounded theory approach proposed by Charmaz (2006). In this study, the researcher used triangulation approach which involved two types of data collection namely interviews and focus groups.

\section{Findings}

The finding of the study indicated that school guidance and counseling was lost in the midst of systemic processes. It was collectively communicated by most participants in the respective school. This issue had considerably affected the overall school scenario as well as the participants' positive engagement with counselling services. Most of the participants-especially the counsellors, teachers and administrators-mentioned the students' resistance to counselling and learning processes, in favor of their part-time jobs after school. They mentioned that the harsh economic realities facing the students played a decisive role in whether school was the most viable option for the students. The lack of family support and encouragement that the students received further confounded the decision between school and work. This was mentioned by the school administrator as below:

"As for the underachievers, they cannot see the importance of knowledge in their lives. The attractions outside school lure them to work as part timers to earn extra money. They don't see the effect of working on their academic performances. In addition, some of them come from broken families who urge them to work to support their lives. They usually do the job after school until the early hours of the morning, which makes them sleepy, tired, and less focused in school the next day. There are students who are forced to come to school just for the sake of getting money from their parents. When they are here, they can easily eat at the school canteen. They choose to come to school rather than stay at home, as they can avoid helping their parents with household chores. There are cases of students opting to come to school just to kill time and escape from the uncomfortable conditions facing them at home like crowded and stuffy houses".

One referred client also admitted that due to his involvement in part time job had made him sleepy in the classroom.

"I spend the rest of my time in classroom sleeping"

"I did not bother having my lunch for the sake of sleeping. I slept from the first morning lesson until the last teaching period of the day".

(Student 2- Referred client)

Counsellor A, B and C also expressed their dismay concerning the irresponsible parents who left it to the school to carry on the burden of nurturing their children's well-being.

“..//.. there was a parent who came and scolded me asking why I couldn't take care and find their son whereabouts. They didn't understand their role. They just let the school take care of their children's well-being".

"..//.. only 30 parents turned up (during a parentteacher meeting) although the school has 3,000 students".

The school's structural system also provides certain implications for the participants. The students in the research context showed their estrangement not only from their lessons but also from the school community. The referred clients spoke of reacting negatively to the institutional power structure of the school and employing behavioral tactics that constitute part of a "culture of resistance" which is anti-school. Similarly, those participants especially who were not involved in counselling did not feel that the teachers and counsellors were concerned about their interests. They reported that they neither obtain genuine concern and understanding from the school community nor do they feel that they owe the teachers any respect. They generally perceived that the school system is more interested in maintaining authority and discipline than in providing education. In such a context, the students are less cooperative with teachers who are seen to be disrespectful to them and uninterested in their welfare. The issues of authority, power and respect represented the disparate power relations which exist within schools and were, thus, seen as areas of resistance. These statements were explained by them as below:

"I don't understand what the hell the teacher is teaching us. Every time we are asked to copy all the things written on the whiteboard without him / her trying to explain to us... so why the heck should I be sitting in the classroom doing things that I don't understand at all"?

The other issue that was raised by school counsellor (C) and school teacher was the school disciplinary system, which was considered weak due to the poor monitoring system. It was no surprise that students tended to be disrespectful of the school rules and dared to make fun of them.

"I can say there are a pros and cons in this system. There are many cases in which no action is taken against students, even though they have earned 600 or 700 points. One student boasted that despite having earned 600 points, he wasn't afraid of getting suspended from school (200 points were the maximum points leading to suspension). They also observed many cases in which their friends who were suspended from school managed to re-enrol... they didn't bother at all about how many penalty points they had accrued".

Similar views were also communicated by other students regarding school guidance and counselling services.

"..//.. if you happen to be counselled, you will find lots of condemning and blaming words all around 
you ... even if you don't understand what the hell they are talking about ... you need to endure your ears listening to their lectures for hours and hours. It was so irritating ..."

(Student A - Focus group 1)

"Counselling has its own existing image. When people coin the term 'counselling', automatically it signifies the students who have committed disciplinary problems; and hence it prevents other students from getting close to counselling".

"I think the most important issue is peers' influence. Most of them said counselling is not good ... being in a counselling room is just like living in hell".

(Student B - Focus group 1)

"I have an experience with two Malay female students.. One of them said what the heck is counselling for. Its bullshit, she even burst out with lots of condemning and nonsense words. I tried to persuade her to enter the room. Surprisingly she refused by saying she would never set foot inside, never. Then I asked her why? She said counselling is only meant for students in trouble, if I were to be here, surely I will be terminated from my post as a school prefect and my mother always warned me not to come here because this room is not meant for me; it is only for those (troubled) groups".

(School counsellor B)

"Referred students consider counselling as part of school games and tricks. They neither understand the exact role of counselling nor know the purpose of their suspension from school".

(School counsellor D)

Besides that, an improper school environment was also contributing to this bad situation. A high number of students and the poor quality of the physical infrastructure had added to the deteriorating situation. These situations were mentioned by the school teacher known as Madam $\mathrm{K}$ and the school administrator, Madam F as below:

"Due to the high number of students, we cannot easily manage to control their attendance in the extracurricular activities.

Classrooms are not comfortable. For example, upper six students have been placed in the science lab and need to endure sitting in the tiny lab chairs".

..//..Our system has made the students even more mischievous.

"I'm not a racist, but as far as I have observed, I can say that the Indian and Chinese students are not really concerned with the school cleanliness. They dare to throw rubbish everywhere, especially along the classroom corridors. I have spoken to students so many times during the school assembly, reminding them to take care of the school cleanliness. Unfortunately, my efforts were in vain. They do not seem to be bothered about it at all and keep on repeating the same bad behaviour. As a result, the school cleaners need to double their efforts to pick up the rubbish dumped by the students every day".

Madam K also reiterated her concerns about the number of students who she considered to be out of control. She framed them in these shocking analogies:

"Staying in this school is like living in a cow or goat shed. The situation cannot be controlled anymore... Seriously, the huge amount of students in this school is just like sardines in a can. The Ministry still accepts the failed students. That is why the school's situation is becoming worse".

..//..This school is so boring because of its system.

Similar views were also explained by the school administrator.

"Teachers are also having problems with the school's infrastructure. Besides facing limited and stuffy spaces for their rooms, they also need to endure placing themselves in a very small meeting room".

\section{(Madam F)}

According to Madam F, there were only 186 teachers to cater for 3,490 students. This indicates that the teacher-student ratio was about 1:19, while in the classroom, the ratio would be $50: 1$. This ratio signified the extra burden carried by the schoolteachers in managing students in the school, as well as encountering their attitude in the classroom. This situation was an additional cause of distress to the teachers, as they had to face turbulent and chaotic classrooms.

Madam Y who was also the school administrator seemed to admit that the large number of students did not strike a good balance with the school's capacity.

"Our greatest challenge so far is in terms of managing students' disciplinary problems. At this point, we have to deal with the large number of students. Can you imagine the chaotic situations that we have to face with 50 classes in the morning session and 40 in the afternoon? I would say, out of 15 classes of Form 5, 5 of them are good while the rest are not. As administrators, we have to understand that not all teachers are able to endure this situation. There are times that their emotions are out of control".

(Madam Y)

According to school counsellor, known as Madam D, the poor condition of school infrastructure; (main hall) had indirectly affected guidance and counselling service.

//.. as you can see the condition of the hall is not really conducive, no sound proof and the worst part is that it is really hot ...

(School Counsellor B)

I think the number of teachers does not sufficiently accommodate the needs of high number of students.

In addition, according to Madam D, the large number of students posed certain pressure on school counsellors as they had to priorities troublesome students rather than concentrating on the well-being of the well-behaved students.

"I do understand and admit that the large number of students is beyond the counsellors' control. Furthermore, they need to give priority to 
the neediest students rather than concentrate on non-threatening cases".

"Due to the high number of students, they (troublesome students) take the opportunity to play truant because they believe that the teachers do not bother about their situation".

"They become involved in truancy because they are not interested in studies".

\section{Discussion}

The findings of the study indicated systemic issues were the major problems that contributed to students' negative values towards guidance and counselling services. The four key relationships of school climate (i.e., the relationships of student to self, student to peers, student to parent and community and student to teacher, and administrators) was not positively exhibited by the participants. Indeed, the school had become powerless in establishing a good relationship between them, as it was unable to deal with the students' behavior (Gottfredson, 1990), and thus, inhibited a sense of cohesion and successful student outcomes (Stewart, 2008). The findings are also in agreement with Stewart (2008), who mentioned that a school's experiences of higher levels of disorder relate to the situations where students do not believe they belong or feel cared for by the school personnel.

The study indicated that the issue of the large number of students, the lack of physical facilities in the school and inadequate space for developing the students' potential and capabilities had contributed to the school's structural problems. These problems carry implications for the rest of the school system, including learning processes as well as students' attitudes towards school guidance and counselling services. These situations echo the findings of Dei et al. (2007), who indicated that the negative values of students and the school system could adversely affect the overall school climate, possibly turning the school into a chaotic environment. In a similar vein, Patton and McMahon's (2006) assert that these elements (i.e. structural problems and students' attitudes) work in circular rather than linear patterns in which they are mutually influencing each other.

\section{Implications of systems theory framework}

The findings of the study fit into the STF that emphasizes the interconnectedness and the importance of wholes rather than parts. According to McLeod (2003), each part of a system plays certain roles and performs specific tasks within the system. Crucially, change in any one part affects the rest of the system. The study shows that the changing of students' values and attitudes carries implications for the rest of the school systems, including learning processes, as well as their values towards school guidance and counselling services. Thus, understanding the participants' contextual background is important. Their behavior cannot be accounted for in a linear way, as individuals actively participate in the creation of their own reality. Therefore, understanding the school structural system is important in comprehending the participants' values towards counselling services.

The research also showed that the effort to understand counselling is not only established between the client and counsellor but also with the school system. Throughout recent history, emphasis has been placed largely by school guidance and counselling in Malaysia as well as across the globe on the importance of individualizing problems as a response to individual suffering and individual needs. However, as we are now living in a complex social system, there is a need to understand school counselling on a systemic level (Low, 2009). According to McLeod (2003), there is a need to understand the principles by which systems operate and the types of intervention that can bring about change on a systemic level. He stressed that the organizational factors characterized by the type of agency or setting, and the way it is organized, may have an impact on many aspects of counselling. Furthermore, Anderson et al. (1986) mentioned that "problems are not the result of an objective defect that exists within or between individuals, but rather, the distinction of the system of treatment of concern is defined by those who share in the communication that defines the problem". Hence, good understanding of the school ethos and systems is essential for all counsellors. In this vein, it is asserted that the examination of organizational values, beliefs and practices in relation to professional values, beliefs and training may inform capacity building for counsellors. This involves the process of providing effective counselling strategies involves counsellors' self-reflexivity. Counsellors need to examine their worldviews and, at the same time, try to understand others and have the awareness that they are not only working with their clients but with systems. Proactive efforts must be taken by school counsellors to resolve this issue. A holistic perspective enables individuals to recognize the themes and interconnectedness among various behaviors (Jackson and Meadows, 1991).

Immersing in the research process made the researcher understand the influence of a system on the values and attitudes of human beings. It is about time for guidance and counselling services to enhance their quality and to regain support from the school community by strengthening their roles. This is in accordance with McLeod (2003), who encouraged counsellors to play a more active part in facilitating organizational change. This involves the act of educating the school community about the role of counselling as well as establishing a viable relationship with this community. In the context of the researched school, more outreach promotions can be conducted to spread awareness about the service. Various efforts need to be made to demystify the actual meaning of guidance and counselling. This can be done by establishing collaboration with the 
school community (Clark and Breman, 2009) especially teachers and school administrators, in conducting programs. Once counsellors have gained acceptance and respect in the staffroom, they can then fulfil a more specific counselling role. This is in line with the suggestion made by Akos (2005) that school counselling requires a unique design and responsive developmental programs to cater to the needs of the school community. In this context, counsellors and the school community need to find a better way to restore a positive relationship and a supportive environment within the school community. Establishing advisory programs and teaming, for example, could help improve teachercounsellor-student relationships, promote social and emotional development as well as build feelings of belonging and caring.

\section{Conclusion}

Indeed, this framework has given the insights into connecting the researcher's wide-ranging ideas into a more coherent whole. The conceptions of an individual in a system demonstrated by STF enable the researcher to explain the nature of human behavior as a dynamic and fluid process. Through the process of recursiveness and chance, it clearly displays the fluid conception of human interaction. Therefore, this framework gives due consideration to the dynamic elements surrounding human beings in a system is helpful in understanding school communities' cultural values towards the service. Furthermore, this framework has opened up the possibilities to narrow down the understanding concerning this issue.

\section{References}

Adams J, Benshoff J and Harrington S (2007). An examination of referrals to the school counselor by race, gender, and family structure. Professional School Counseling, 10(4): 389-398.

Akos P (2005). The unique nature of middle school counseling. Professional School Counseling, 9(2): 95-103.

Akos P, Hamm JV, Mack SG and Dunaway M (2006). Utilizing the developmental influence of peers in middle school groups. The Journal for Specialists in Group Work, 32(1): 51-60.

Anderson H, Goolishian H, Pulliam G and Winderman L (1986). The Galveston family institute: Some personal and historical perspectives. In: Efron DE (Eds), Journeys: Expansion of the strategicsystemic therapies, Brunner/Mazel, New York, USA: 97-122.

Charmaz K (2006). Constructing Grounded Theory. SAGE Publications Ltd, London, UK.

Clark MA and Breman JC (2009). School counselor inclusion: A collaborative model to provide academic and social-emotional support in the classroom setting. Journal of Counseling and Development: JCD, 87(1): 6-11.

Dei GJS, Mazzuca J, McIsaac E and Zine J (2007). Reconstructing 'Drop-Out': A critical Ethnography of the dynamics of Black Students' disengagement from school. University of Toronto Press, Toronto.

Gottfredson DC (1990). Developing effective organizations to reduce school disorder. In: Moles O (Eds), Strategies to reduce student misbehavior. Office of Educational Research and Improvement, Washington, USA: 87-104.

Hui EKP (2002). A whole-school approach to guidance: Hong Kong teacher' perceptions. British Journal of Guidance and Counselling, 30(1): 64-80.

Jackson AP and Meadows FJr. (1991). Getting to the bottom to understand the top. Journal of Counseling and Development, 70(1): 72-76.

Li CS (2004). Students' reluctance in seeking counselling: A case study in a secondary school in Kuching, Sarawak. M. Sc. Thesis, University of Malaya, Kuala Lumpur.

Low PK (2009). Considering the challenges of counselling practice in schools. International Journal for the Advancement of Counselling, 31(2): 71-79.

Loynd C, Cooper M and Hough M (2005). Scottish secondary school teachers' attitudes towards, and conceptualisations of, counselling. British Journal of Guidance and Counselling, 33(2): 199-211.

McLeod J (2003). An Introduction to counselling. $3^{\text {rd }}$ Edition, Open University Press, Buckingham, UK.

Patton W and McMahon M (2006). The systems theory framework of career development and counseling: Connecting theory and practice. International Journal for the Advancement of Counselling, 28(2): 153-166.

Ponterotto JG (2005). Qualitative research in counseling psychology: A primer on research paradigms and philosophy of science. Journal of Counseling Psychology, 52(2): 126-136.

Rusnani AK, Poh FL and Asmah I (2008). Hubungan pengalaman melalui kaunseling dan sikap mendapat bantuan kaunseling. Persatuan Kaunseling Malaysia (PERKAMA), 14: 97-106.

Salim S (2010). Psychological help seeking attitudes among Malaysian College and university students. Procedia-Social and Behavioral Sciences, 5: 426430.

Sapora S (2007). The status and future challenges of school guidance and counselling services in Malaysia. Persatuan Kaunseling Malaysia (PERKAMA), 13: 45-57. 
Sidek MN, Nordin K, Yusoff AM, Shamsuddin H and Halaliah MH (2005). Status dan keberkesanan perkhidmatan bimbingan dan kaunseling di sekolah menengah di Semenanjung Malaysia. Jurnal Penyelidikan Pendidikan, 7: 113-131.

Stewart EB (2008). School structural characteristics, student effort, peer associations, and parental involvement: The influence of school- and individual-level factors on academic achievement. Education and Urban Society, 40(2): 179-204.

Yeh CJ (2003). Age, acculturation, cultural adjustment, and mental health symptoms of Chinese, Korean, and Japanese immigrant youths. Cultural Diversity and Ethnic Minority Psychology, 9(1): 34-48. 